\title{
Local Health Departments Addressing the Social Determinants of Health: A National Survey on the Foreclosure Crisis
}

\author{
Katherine Schaffl, 2,** and Lori Dorfman ${ }^{2}$
}

\begin{abstract}
Purpose: To examine local health department (LHD) engagement in addressing the social determinants of health by using the foreclosure crisis as an example.

Methods: National survey of 166 LHD staff on the foreclosure crisis (2006-2014).

Results: About one quarter (28\%) of respondents reported that their LHD had engaged in work related to the foreclosure crisis, $7 \%$ planned to engage, and $65 \%$ did not or were not planning to engage. Views about the role of LHDs in addressing the foreclosure crisis varied: $30 \%$ stated that LHDs should work on foreclosure.

Conclusions: A substantial number of respondents reported that their LHD addressed foreclosure, or supported engagement, yet there are divergent perceptions of appropriate LHD roles. LHDs follow a pattern described by the diffusion of innovations theory: Innovative LHDs can share their work on foreclosure and housing, early adopters are poised to act, and others may follow if they have support.
\end{abstract}

Keywords: foreclosure; health equity; housing; local health departments

\section{Introduction}

The foreclosure crisis drastically reshaped access to housing and wealth in the United States, with widespread health impacts for homeowners, renters with landlords facing foreclosure, and communities with high rates of foreclosure. ${ }^{1,2}$ A homeowner going through foreclosure or a renter whose landlord undergoes foreclosure faces housing instability, a disruption of social networks, and increased financial burden-all of which are associated with negative physical and mental health outcomes, such as hypertension, heart disease, and depression. ${ }^{3-10}$ Communities with high rates of foreclosure often face elevated rates of violent crime and associated poorer health outcomes. ${ }^{5-8}$ Related to patterns of segregation, disinvestment, predatory lending, and decades of policies that harm communities of color and lowerincome communities, the foreclosure crisis disproportionately affected lower-income, African American,
Latinx, and some Asian and Pacific Islander communities and stands to exacerbate racial and class inequities in health for current and future generations. ${ }^{11-13}$

Local health departments (LHDs) are increasingly involved in addressing social determinants of health, such as housing, and supporting communities in building power as strategies to achieve health equity. ${ }^{14,15}$ LHDs can play a unique role in addressing the social determinants of health through: leadership and convening, access to data and decision makers, partnerships with residents and community organizations, mandates and legal authority, and by connecting social factors and health. ${ }^{16-19}$ Housing is a core social determinant of health, and we would accordingly expect LHDs to be responsive to emerging and pressing foreclosure-related concerns and health impacts within their jurisdictions. However, there has been little research on whether and how LHDs engage in addressing

${ }^{1}$ Alameda County Public Health Department, Oakland, California.

${ }^{2}$ Berkeley Media Studies Group-A Project of Public Health Institute, Berkeley, California.

*Address correspondence to: Katherine Schaff, DrPH, MPH, Berkeley Media Studies Group—A Project of Public Health Institute, 2130 Center Street, Suite 302, Berkeley, CA 94607, E-mail: schaff@bmsg.org

() Katherine Schaff and Lori Dorfman 2019; Published by Mary Ann Liebert, Inc. This Open Access article is distributed under the terms of the Creative Commons License (http://creativecommons.org/licenses/by/4.0), which permits unrestricted use, distribution, and reproduction in any medium, provided the original work is properly cited. 
housing and foreclosure as determinants of health. In this research, we begin to address this gap by reporting on a national survey that explores LHD engagement, roles, and responsiveness to the foreclosure crisis.

\section{Methods}

To understand the response of LHDs in the United States to the foreclosure crisis (2006-2014), we designed, pilot-tested with staff from a diverse range of LHDs, and administered an online Qualtrics survey with closed and open-ended questions. Using skip logic, the survey ranged from 5-10 questions regarding ongoing or potential foreclosure-related work, barriers to engagement, and perceptions about whether LHDs should be addressing the foreclosure crisis. The Institutional Review Board at the University of California, Berkeley, approved this study protocol. Survey respondents provided informed consent.

We invited all LHDs in the United States $(\sim 2800)$ by using the National Association of County and City Health Official's LHD Index, and numerous listservs, regional and state public health associations, and personal contacts. To increase the response and completion rate, respondents qualified for a drawing for one of two \$25 gift cards. More than one respondent from each LHD could participate because: we wanted to capture diverse perspectives; staff may know about different work happening within their LHD depending on their job and how large the health department is; and we were focused on exploratory research to gather perceptions rather than statistically generalizing responses to all LHDs. We considered surveys to be complete when respondents advanced through each page and clicked on the link to take them to a final question about participating in the raffle. However, the $\mathrm{N}$ varies per question based on (1) skip logic; (2) some questions were optional; and (3) some respondents chose not to answer specific questions.

One author and another researcher coded all responses by using Qualtrics to analyze close-ended questions and Dedoose for inductive/deductive coding of open-ended questions to identify major themes, resolving differences through consensus. ${ }^{20,21}$

\section{Results}

There were 166 completed surveys from 159 LHDs in 36 states; 7 LHDs had 2 respondents each (Table 1). Respondents were from a mix of township, city, county, and regional LHDs, with the smallest serving 712 residents and the largest serving 9,818,696 residents, based
Table 1. Local Health Department Survey Respondents by State

\begin{tabular}{|c|c|}
\hline No. of respondents & State \\
\hline 0 & $\begin{array}{l}\text { Alabama } \\
\text { Alaska } \\
\text { Delaware } \\
\text { Georgia } \\
\text { Hawaii } \\
\text { Nevada } \\
\text { New Hampshire } \\
\text { New Mexico } \\
\text { Rhode Island } \\
\text { South Carolina }\end{array}$ \\
\hline 1 & $\begin{array}{l}\text { Idaho } \\
\text { Indiana } \\
\text { Louisiana } \\
\text { Maine } \\
\text { Maryland } \\
\text { Michigan } \\
\text { Mississippi } \\
\text { Missouri } \\
\text { Nebraska } \\
\text { Oklahoma } \\
\text { Pennsylvania } \\
\text { South Dakota } \\
\text { Utah } \\
\text { Vermont } \\
\text { Wyoming }\end{array}$ \\
\hline 2 & $\begin{array}{l}\text { Arkansas } \\
\text { Connecticut } \\
\text { Oregon } \\
\text { Tennessee } \\
\text { Virginia }\end{array}$ \\
\hline 3 & $\begin{array}{l}\text { Arizona } \\
\text { Florida } \\
\text { Kentucky } \\
\text { North Carolina } \\
\text { North Dakota } \\
\text { West Virginia }\end{array}$ \\
\hline 4 & Montana \\
\hline 5 & $\begin{array}{l}\text { lowa } \\
\text { Kansas } \\
\text { New Jersey } \\
\text { New York }\end{array}$ \\
\hline 6 & $\begin{array}{l}\text { Colorado } \\
\text { Washington }\end{array}$ \\
\hline 7 & $\begin{array}{l}\text { Illinois } \\
\text { Minnesota }\end{array}$ \\
\hline 11 & California \\
\hline 12 & Wisconsin \\
\hline 14 & Texas \\
\hline 17 & Massachusetts \\
\hline 19 & Ohio \\
\hline
\end{tabular}

on 2010 population estimates of the U.S. Census Bureau (Table 2). Twenty-eight percent of respondents said that their LHD had engaged in work related to the foreclosure crisis, $7 \%$ noted that their LHD was planning to engage in the next year, and $65 \%$ reported that their 
Table 2. Size of Population Served by the Local Health Departments of Survey Respondents

\begin{tabular}{lcr}
\hline Size of population served & No. of respondents & $\%$ \\
\hline$<10,000$ & 21 & 12.65 \\
$10,000-24,999$ & 29 & 17.47 \\
$25,000-49,999$ & 23 & 13.86 \\
$50,000-74,999$ & 16 & 9.64 \\
$75,000-99,999$ & 17 & 10.24 \\
$100,000-199,999$ & 21 & 12.65 \\
$200,000-499,999$ & 16 & 9.64 \\
$500,000-999,999$ & 13 & 7.83 \\
$1,000,000+$ & 10 & 6.02 \\
Total & 166 & \\
\hline
\end{tabular}

Due to rounding, percentages may not add up to $100 \%$.

Population data used for analyses are based on 2010 population estimates of the U.S. Census Bureau.

LHD was not engaging or planning to engage in work related to foreclosure (Table $3, n=166$ ). Thirty percent believed that their LHD should work on foreclosure, $46 \%$ thought that their LHD should not engage, and $24 \%$ selected "other" with the option to provide additional comments, many of which described barriers and challenges to the work $(n=160)$.

Of the respondents who answered questions about how they engaged $(n=43)$, meeting with other city and county agencies to discuss and plan responses to the foreclosure crisis (44\%) and communicating with community organizations that address foreclosure $(40 \%)$ were the

\section{Table 3. Survey Responses from Local Health Department Staff to "Has Your Health Department Engaged in Any Work in Response to the Foreclosure Crisis (2006-2014)?" Classified by Mutually Exclusive Diffusion of Innovation Categories ( $n=166$ Respondents)}

\begin{tabular}{|c|c|c|c|}
\hline $\begin{array}{l}\text { Potential } \\
\text { diffusion } \\
\text { of innovations } \\
\text { category }\end{array}$ & Answer & Response & $\%$ \\
\hline $\begin{array}{l}\text { Innovators/ } \\
\text { early adopters }\end{array}$ & Yes & 47 & 28 \\
\hline $\begin{array}{l}\text { Early/ } \\
\quad \text { late majorities }\end{array}$ & $\begin{array}{l}\text { No, we have not engaged in } \\
\text { any work related to foreclosure, } \\
\text { but are planning on engaging } \\
\text { in work related to foreclosure } \\
\text { in the next year. Please describe } \\
\text { what type of work you will be } \\
\text { engaging in: }\end{array}$ & 11 & 7 \\
\hline \multirow[t]{2}{*}{ Laggards $^{a}$} & $\begin{array}{l}\text { No, we have not engaged } \\
\text { in any work related } \\
\text { to the foreclosure crisis } \\
\text { and do not plan on } \\
\text { engaging in work related } \\
\text { to foreclosure. }\end{array}$ & 108 & 65 \\
\hline & Total & 166 & 100 \\
\hline
\end{tabular}

${ }^{\mathrm{a}}$ This language comes from Diffusion of Innovations theory. Health departments in this category may have compelling reasons for not engaging in the foreclosure crisis, such as budget and staffing cuts or other emerging threats.
Table 4. Survey Responses from Local Health Department Staff to "You Indicated Your Health Department Has Engaged in Work in Response to the Foreclosure Crisis (2006-2014)"a

\begin{tabular}{|c|c|c|}
\hline Answer & Response & $\%$ \\
\hline $\begin{array}{l}\text { Met with other city or county agencies to discuss } \\
\text { and plan responses to the foreclosure crisis }\end{array}$ & 19 & 44 \\
\hline Other: Please describe & 18 & 42 \\
\hline $\begin{array}{l}\text { Communicated with community organizations } \\
\text { that are addressing foreclosure }\end{array}$ & 17 & 40 \\
\hline Advocated for local policies related to foreclosure. & 15 & 35 \\
\hline $\begin{array}{l}\text { Reached out to/communicated with local } \\
\text { banks/finance groups regarding the } \\
\text { foreclosure crisis }\end{array}$ & 14 & 33 \\
\hline $\begin{array}{l}\text { Communicated with the media about the } \\
\text { impact of foreclosure on health }\end{array}$ & 10 & 23 \\
\hline $\begin{array}{l}\text { Provided data or research regarding the health } \\
\text { impacts of foreclosure to partners, policymakers, } \\
\text { advocates, or the media }\end{array}$ & 7 & 16 \\
\hline $\begin{array}{l}\text { Released reports, factsheets, articles, blogs, or } \\
\text { other information on foreclosure and health, } \\
\text { either independently or in collaboration } \\
\text { with other organizations }\end{array}$ & 7 & 16 \\
\hline $\begin{array}{l}\text { Coordinated physical and/or mental health } \\
\text { service provision with organizations } \\
\text { providing foreclosure counseling } \\
\text { or other services }\end{array}$ & 7 & 16 \\
\hline $\begin{array}{l}\text { Provided targeted physical and/or mental } \\
\text { health services to those facing foreclosure }\end{array}$ & 5 & 12 \\
\hline $\begin{array}{l}\text { Provided formal testimony or communicated } \\
\text { to policymakers regarding the health } \\
\text { impact of the foreclosure crisis }\end{array}$ & 5 & 12 \\
\hline $\begin{array}{l}\text { Analyzed local lending patterns in } \\
\text { communities affected by the foreclosure crisis }\end{array}$ & 2 & 5 \\
\hline
\end{tabular}

$n=47 / 166$ respondents were eligible to answer this question because of skip logic; responses not mutually exclusive.

${ }^{a}$ This question only appeared in surveys for respondents who said their health department engaged in work related to the foreclosure crisis. Longer descriptions/examples of each activity were given in the survey.

most common responses (Table 4). Just more than onethird advocated for local polices related to foreclosure (35\%), and one-third contacted local banks and finance groups (33\%). The majority $(64 \%, n=41)$ said there were fewer than five staff working on the issue.

Respondents described seven roles for LHDs, from no engagement to deeply engaged (Table $5 ; n=165$ responses). Eight responses (4.8\%) suggest no role for LHDs because other social determinants, such as poverty, were a more urgent local priority or because foreclosure had not been raised by clients during clinic visits. Fourteen responses (8.5\%) indicate that LHDs could have a role but that it is unclear what it should be. More responses (35 or 21.2\%) define the role of LHD as connecting clients to services and case management to mitigate the impacts of foreclosure on individuals. Most responses (47 or $28.5 \%$ ) connect the role of LHD to environmental health impacts, specifically mandated and regulatory activities such as addressing nuisance complaints to holding banks accountable for 
Table 5. Survey Respondents' Perceptions About the Role of Local Health Departments in Addressing the Foreclosure Crisis (2006-2014) Moving from No Role to Deeply Engaged ( $n=165$ Coded Responses)

\begin{tabular}{|c|c|c|}
\hline Perception of LHD role & $\begin{array}{l}\text { No. of responses } \\
\text { that describe } \\
\text { this role } \\
\text { (not mutually } \\
\text { exclusive) }\end{array}$ & Examples and quotes \\
\hline $\begin{array}{l}\text { No role: Did not think } \\
\text { it was necessary } \\
\text { for LHDs to address } \\
\text { foreclosure. }\end{array}$ & 8 & $\begin{array}{l}\text { - "It's not a part of our mission nor is it considered core public health. } \\
\text { Our hope is this issue would be addressed by other, } \\
\text { more appropriate agencies." } \\
\text { - "We are located in Appalachia where poverty has always been an issue. } \\
\text { The foreclosure crisis hasn't had a significant impact on chronic poverty issues." }\end{array}$ \\
\hline $\begin{array}{l}\text { Unclear role: Believe LHDs } \\
\text { could have a role, } \\
\text { but unclear what that } \\
\text { role should be. }\end{array}$ & 14 & $\begin{array}{l}\text { - "We are just beginning to explore ways to more directly address upstream, } \\
\text { root causes for some of the health challenges we see. Public health in } \\
\text { general is upstream, but we are trying to determine just how } \\
\text { far upstream we should go." }\end{array}$ \\
\hline $\begin{array}{l}\text { Connectors: LHDs should } \\
\text { connect clients } \\
\text { to services, health } \\
\text { care, and case } \\
\text { management. }\end{array}$ & 35 & $\begin{array}{l}\text { - "Other than referring clients to programs that are designed to assist, } \\
\text { we have so much other work. We can only advocate for more assistance." }\end{array}$ \\
\hline $\begin{array}{l}\text { Address environmental issues: } \\
\text { LHDs should focus } \\
\text { on environmental } \\
\text { health and safety } \\
\text { related to housing. }\end{array}$ & 47 & $\begin{array}{l}\text { - "Our sewage code requires us to take legal action when property } \\
\text { owners fail to follow the code." } \\
\text { - "We have found putting the pressure on the bank that holds the } \\
\text { mortgage does help with enforcement to secure the property } \\
\text { and maintain the property so that it is safe." }\end{array}$ \\
\hline $\begin{array}{l}\text { Conduct assessments: } \\
\text { LHDs should conduct } \\
\text { community assessments } \\
\text { or data analysis. }\end{array}$ & 9 & $\begin{array}{l}\text { - "Working on doing a community health assessment and } \\
\text { community health improvement plan; foreclosure would be part of that." }\end{array}$ \\
\hline $\begin{array}{l}\text { Partner with other } \\
\text { organizations: } \\
\text { LHDs should work } \\
\text { with other government } \\
\text { and/or community-based } \\
\text { entities. }\end{array}$ & 22 & $\begin{array}{l}\text { - "It depends on other factors. If we were putting together a city-wide } \\
\text { team of key departments, health should be part and I would } \\
\text { welcome this opportunity." }\end{array}$ \\
\hline $\begin{array}{l}\text { Address social determinants } \\
\text { of health, including } \\
\text { foreclosure: } \\
\text { LHDs should address } \\
\text { social factors } \\
\text { that affect health, } \\
\text { such as foreclosure } \\
\text { and housing. }\end{array}$ & 30 & $\begin{array}{l}\text { - "In a sense, it is a community disaster. Responding to such disasters } \\
\text { and crises to preserve and restore health is a core public health function." } \\
\text { - Many respondents included terms such as "economics," } \\
\text { "low-income communities," "poverty," or "certain communities." } \\
\text { Only one respondent used the term "communities of color," } \\
\text { which was the only comment in this category that more explicitly } \\
\text { raised racial inequities related to foreclosure. }\end{array}$ \\
\hline
\end{tabular}

Responses are not mutually exclusive. For example, one response may be coded as partnering with other organizations as well as conducting assessments.

LHD, local health department.

property maintenance. Nine (5.5\%) responses describe a role for LHDs in conducting community assessments or data analysis related to foreclosure. Twenty-two (13.3\%) responses define partnering with others as a key role. Finally, 30 responses (18.2\%) suggest that LHDs should address foreclosure as a social determinant of health that drives health inequities.

\section{Discussion}

The foreclosure crisis, and more broadly, housing, will continue to affect public health broadly, including racial and economic disparities in health. ${ }^{22,23}$ As little re- search has examined LHD staff perceptions about the role of LHDs in addressing social determinants of health, such as foreclosure or housing, the wide variation in both opinions on appropriate roles for LHDs and current LHD work related to foreclosure is a significant finding.

Diffusion of innovations theory describes how new ideas or practices are adopted within or across organizations. $^{24}$ This research suggests that LHDs are moving through a diffusion of innovations process, with fewer innovators and early adopters engaging in addressing foreclosure and housing as one strategy in tackling 
health inequities; early and late majority LHDs contemplating engagement; and other LHDs with no plans for engagement (Table 3). Although fewer LHDs are working on policy change related to foreclosure, these results demonstrate that innovative LHDs, despite challenges, are expanding the boundaries of local public health practice and developing new roles and strategies for LHDs to address social determinants of health, such as the foreclosure crisis. Implications for practice include developing case studies or resources based on lessons from innovative LHDs and better understanding and addressing barriers that LHDs face.

The results led us to question why some innovative LHDs have addressed foreclosure, specifically through policy and community partnerships, whereas others have yet to engage. Future analysis of these data will examine the variability in responses across LHDs, including factors that facilitate innovation as well as barriers that LHDs face in addressing the foreclosure crisis, and will likely be relevant to LHDs working to address other social determinants of health. ${ }^{25}$

\section{Limitations}

Although this study illuminates the role of LHD in addressing the foreclosure crisis, it has several limitations. It is not representative of LHDs in the United States nor generalizable. The LHD staff who self-selected to take the survey may differ in significant ways from staff who did not take it, and the work that their LHD does may also differ. Survey responses were brief and do not reflect the full knowledge or perceptions of respondents. Finally, there are limitations to survey methodology, such as the influence of wording and the order of questions, and specific limitations related to online surveys. However, given the lack of research on LHD engagement in addressing social determinants of health, this survey helps build the foundation for future research and action.

\section{Conclusion}

As a growing number of LHDs tackle the root causes of health inequities through addressing the social determinants of health such as housing and foreclosure, research on challenges, opportunities, and LHD staff views of their own role in confronting these issues is essential to achieving health equity.

Catalyzing and accelerating innovation across LHDs is a critical step in advancing public health practice focused on addressing the social determinants of health. Our results indicate there are innovative LHDs that can share lessons learned and best practices, early adopters ready to take on this work, and early and late majority LHDs who may be able to soon follow if challenges are met and they are provided with support. Future research on the characteristics and approaches that LHDs have and use, the systems and contexts they work within, and the barriers they face can provide clear, concrete steps for advancing public health practice and ensuring that LHDs use their unique role to help the country move toward racial and health equity.

\section{Acknowledgments}

The authors would like to acknowledge Ann Keller, john powell,* and Len Syme for guidance; Jon Ashworth, Michael Isaacson, Ruvani Fonseka, Solange Gould, Ryan Petteway, and David Rebanal for providing feedback on the survey tool; and Solange Gould for coding responses and helping in the development of the codebook. ${ }^{\star}$ Professor john powell does not capitalize his name.

\section{Author Disclosure Statement}

No competing financial interests exist.

\section{References}

1. Downing $\mathrm{H}$. The health effects of the foreclosure crisis and unaffordable housing: a systematic review and explanation of evidence. Soci Sci Med. 2016;162:88-96.

2. Tsai AC. Home foreclosure, health, and mental health: a systematic review of individual, aggregate, and contextual associations. PLoS One. 2015;10:1-21.

3. Bennett GG, Scharoun-Lee M, Tucker-Seeley R. Will the public's health fall victim to the home foreclosure epidemic? PLoS Med. 2009;6:e1000087.

4. Cannuscio CC, Alley DE, Pagán JA, et al. Housing strain, mortgage foreclosure, and health. Nurs Outlook. 2012;60:134-142, 142.e1.

5. Currie J, Tekin E. Is there a link between foreclosure and health? National Bureau of Economic Research. 2011. Available at www.nber.org/papers/ w17310 Accessed December 7, 2012.

6. Phillips D, Clark R, Lee T, et al. Rebuilding Neighborhoods, Restoring Health: A Report on the Impact of Foreclosures on Public Health-Preliminary Report. Oakland, CA: Causa Justa::Just Cause, Alameda County Public Health Department, 2009. Available at www.acphd.org/data-reports/ reports-by-topic/social-and-health-equity.aspx Accessed December 1, 2018.

7. Phillips D, Clark R, Lee T, et al. Rebuilding Neighborhoods, Restoring Health: A Report on the Impact of Foreclosure on Public Health. Oakland, CA: Causa Justa::Just Cause, Alameda County Public Health Department, 2010. Available at www.acphd.org/data-reports/reports-by-topic/social-andhealth-equity.aspx Accessed December 1, 2018.

8. Pollack CE, Lynch J. Health status of people undergoing foreclosure in the Philadelphia region. Am J Public Health. 2009;99:1833-1839.

9. Pollack CE, Lynch J, Alley DE, et al. Foreclosure and health status. Leonard Davis Inst Health Econ. 2010;15:1-4.

10. Fowler KA, Gladden RM, Vagi KJ, et al. Increase in suicides associated with home eviction and foreclosure during the US housing crisis: findings from 16 National Violent Death Reporting System states, 2005-2010. Am J Public Health. 2015;105:311-316.

11. Rugh JS, Massey DS. Racial segregation and the American foreclosure crisis. Am Sociol Rev. 2010;75:629-651.

12. Rogers $C$, * powell ja, eds. Where Credit Is Due: Bringing Equity to Credit and Housing after the Market Meltdown. Lanham, Maryland: University Press of America, 2013. *Professor john powell does not capitalize his name.

13. Johnson R. Health dynamics and the evolution of health inequality over the life course: the importance of neighborhood and family background. BE J Econ Anal Policy. 2012;11:1-69. 
14. Gaydos M, Farhang L. Advancing Health Equity in Health Department's Public Health Practice: Recommendations for the Public Health Accreditation Board. Alexandria, VA: Public Health Accreditation Board, 2018.

15. Human Impact Partners. HealthEquityGuide.org-A Human Impact Partners project. Available at http://healthequityguide.org Accessed July 20, 2017.

16. Pomeranz JL. The unique authority of state and local health departments to address obesity. Am J Public Health. 2011;101:1192-1197.

17. National Association of County and City Health Officials. Operational Definition of a Functional Local Health Department. Washington, DC: National Association of County and City Health Officials, 2005.

18. National Association of County and City Health Officials. Statement of Policy: Foundational Public Health Services. Washington, DC: National Association of County and City Health Officials, 2016.

19. Public Health Accreditation Board. Guide to National Public Health Department Initial Accreditation. Alexandria, VA: Public Health Accreditation Board, 2015.

20. Fereday J, Muir-Cochrane E. Demonstrating rigor using thematic analysis: a hybrid approach of inductive and deductive coding and theme development. Int J Qual Methods. 2006;5:1-11.

21. Campbell JL, Quincy C, Osserman J, et al. Coding in-depth semistructured interviews: problems of unitization and intercoder reliability and agreement. Sociol Methods Res. 2013;42:294-320.
22. Hall M, Crowder K, Spring A, et al. Foreclosure migration and neighborhood outcomes: moving towards segregation and disadvantage. Soc Sci Res. 2018;70:107-114.

23. Phillips D, Flores Jr L, Henderson J. Development Without Displacement: Resisting Gentrification in the Bay Area. Oakland: Causa Justa::Just Cause, 2014.

24. Rogers EM. Diffusion of Innovations. New York: Free Press, 2003.

25. Schaff K. Local Health Departments Engaging in Policy Change to Achieve Health Equity: An Examination of the Foreclosure Crisis [Doctoral Thesis]. Berkeley, CA: University of California, Berkeley, 2015.

Cite this article as: Schaff K, Dorfman L (2019) Local health departments addressing the social determinants of health: a national survey on the foreclosure crisis, Health Equity 3:1, 30-35, DOI: 10.1089/ heq.2018.0066.

\section{Abbreviation Used}

$\mathrm{LHD}=$ local health department

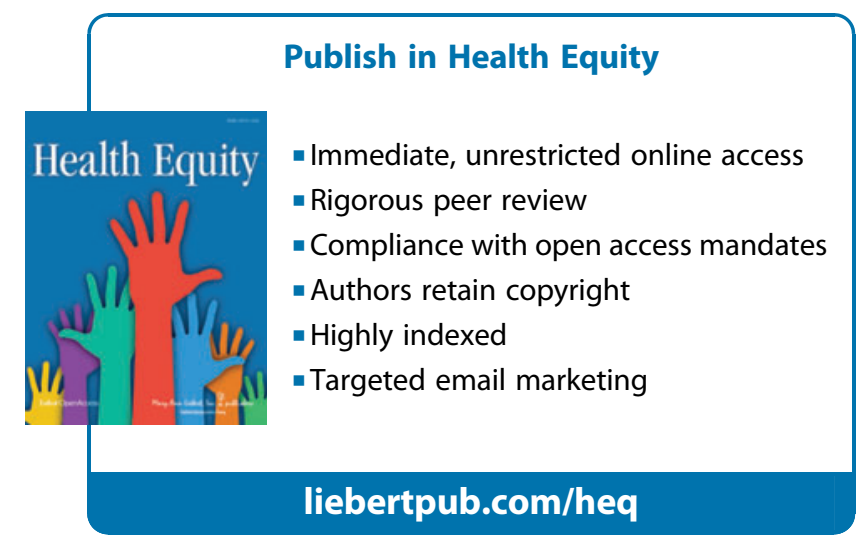

